\title{
Effect of Varying Ratios and Rates of Enriched Cattle Manure on Leaf Nitrogen Content, Yield and Quality of Tea (Camellia sinensis)
}

\author{
Isaiah Masinde Tabu ${ }^{1}$, Vivian Moroamoche Kekana ${ }^{1}$ \& David Murathe Kamau ${ }^{2}$ \\ ${ }^{1}$ Department of Crops, Horticulture and Soils, Egerton University, Kenya \\ ${ }^{2}$ Department of Chemistry, Tea Research Foundation of Kenya, Kericho, Kenya \\ Correspondence: Isaiah Masinde Tabu, Department of Crops, Horticulture and Soils, P.O. Box 536, Egerton \\ University, Kenya. Tel: 254-733-939-181. E-mail: immtabu@yahoo.com
}

\author{
Received: December 5, 2014 Accepted: March 2, 2015 Online Published: April 15, 2015 \\ doi:10.5539/jas.v7n5p175 URL: http://dx.doi.org/10.5539/jas.v7n5p175
}

\begin{abstract}
Tea (Camelia sinensis) a major cash crop in Kenya is normally grown on highly weathered and strongly acidic soils. Non-judicial use of the recommended inorganic compound fertilizer 25:5:5:5s acidifies the soil and pollutes water masses. Integrated soil fertility management, the combined use of organic and inorganic fertilizer is recommended for higher tea yield and soil health. An experiment was carried out in the Eastern Highlands of Kenya to determine the effect of different ratios and rates of enriched cattle manure on leaf nitrogen content, yield and quality of tea. Inorganic compound fertilizer 25:5:5:5s led to the highest $\mathrm{N}$ level in the mature leaf. Enriching organic manures with inorganic fertilizers increased the yield but reduced the quality. Tea quality parameters Theaflavins (TF) and Thearubigins decreased with increase in fertilizer rate irrespective of fertilizer type. Caffeine content however increased with increasing rate fertilizer especially in the case of inorganic compound fertilizer 25:5:5:5. Enriching organic manures with inorganic fertilizers increased the $\mathrm{N}$ content in the mature leaf and crop yield but reduced the quality. The study showed the beneficial effect of enriched manures in tea production.
\end{abstract}

Keywords: enriched cattle manure, inorganic fertilizer, tea (Camellia sinensis), yield and quality of tea

\section{Introduction}

Tea (Camellia sinensis) contributes about $26 \%$ of the total export earnings of Kenya. The crop is grown on acidic highly weathered soils in the highlands of Kenya. Continuous harvesting (two leaves and a bud) of the crop often leads to mining of major nutrients (N, P and K) from the soil. A yield of $5000 \mathrm{~kg}$ made tea per hectare results in about $250 \mathrm{~kg} \mathrm{~N}, 50 \mathrm{~kg} \mathrm{P}_{2} \mathrm{O}_{5}$, and $120 \mathrm{~kg} \mathrm{~K}_{2} \mathrm{O}$ removal from the soil (Kamau et al., 2003). Farmers often use more than the recommended (100-200 $\mathrm{kg} \mathrm{N} \mathrm{ha}^{-1}$ ) fertilizer rates in a bid to increase tea yield (Owuor et al., 2002). The practice acidifies the soils (Wanyoko, 1997) and pollutes the environment. Acidic soils have low nutrient use efficiency because of high P fixation (Owino-Gerroh, 1991). Cattle manure, one of the recommended organic fertilizers in Kenya is however limited by the low amount and quality of resource available at farm level.

Integrated Soil Fertility Management (the combined use of organic and inorganic fertilizers) is recommended because of its ability to concurrently increase crop yield and soil health (Vanlauwe et al., 2001). Inclusion of organic fertilizers in cropping systems is generally acknowledged because they enhance soil organic matter, preserve ecological harmony and promote biological diversity (Omare \& Woomer, 2003). The benefits of Integrated Soil Fertility Management (ISFM) have been demonstrated but the challenge is how much and in what proportions the different fertilizer types should be used. An experiment was carried out to determine the effect different rates and ratios of enriched cattle manure on leaf nitrogen content, yield and quality of tea.

\section{Materials and Methods}

\subsection{Site Description}

A long term field experiment was established in 2000 at Kangaita, latitude $0^{\circ} 26^{\prime} \mathrm{S}$, longitude $37^{\circ} 15^{\prime} \mathrm{E}$, and altitude of $2020 \mathrm{~m}$ above sea level using a high yielding clone TRFK $31 / 8$. The soils in this area are the red clays classified as humic acrisols (Li, Wang, \& Steward, 2013). 


\subsection{Treatment Combination}

The treatments were:

T1: NPKS 25:5:5:5;

T2: Cattle manure;

T3: (T2: 11$)$ at a ratio of $1: 2$;

T4: (T2: T1) at a ratio of 1:4.

Each of the treatments was tested at rates $0,75,150$ and $225 \mathrm{~kg} \mathrm{~N}^{-1} \mathrm{year}^{-1}$. The cattle manure was collected from farmers' fields, analyzed for chemical composition (Okalebo et al., 2002) standardized based on the $\mathrm{N}$ content and then applied to the crop (Table 1). The experiment was set up as 4 by 4 factorial laid out in a Randomized Complete Block Design and replicated three times. Each plot had a net area of 14 by 7 bushes spaced at $(1.22$ by 0.61$) \mathrm{m}^{2}$.

\subsection{Laboratory Analysis}

\subsubsection{Cattle Manure}

Organic carbon was determined by wet oxidation using concentrated sulphuric and potassium dichromate and titrated against ferrous ammonium sulphate. The $\mathrm{pH}$ was determined using a glass electrode $\mathrm{pH}$ meter at a ratio of 1:2.5 manure to water (Okalebo et al., 2002).

Table 1. Chemical characteristics of the manure from farmers' fields

\begin{tabular}{ll}
\hline Parameter & Manure \\
\hline $\mathrm{pH}\left(\mathrm{H}_{2} \mathrm{O}\right) 1: 1$ & 7.3 \\
$\mathrm{P}\left(\mathrm{mg} \mathrm{kg}^{-1}\right)$ & 0.28 \\
$\mathrm{~K}\left(\mathrm{~g} \mathrm{~kg}^{-1}\right)$ & 1.31 \\
$\mathrm{Ca}\left(\mathrm{g} \mathrm{kg}^{-1}\right)$ & 0.89 \\
$\mathrm{Mg}\left(\mathrm{g} \mathrm{kg}^{-1}\right)$ & 0.24 \\
$\mathrm{C}(\%)$ & 22.8 \\
$\mathrm{C}: \mathrm{N}$ ratio & 22 \\
\hline
\end{tabular}

Nitrogen was determined by the micro-Kjeldahl procedure that involved digestion with concentrated sulphuric acid at $330^{\circ} \mathrm{C}$ and hydrogen peroxide as an oxidant and selenium as a catalyst. The process was followed by distillation and titration (Okalebo et al., 2002).

Extractable P was determined by the Olsen method (Okalebo et al., 2002) by placing 5 gms of manure in a plastic bottle where $100 \mathrm{ml} 1 \mathrm{M}$ ammonium acetate was added, shaken for 30 minutes, filtered and diluted 10 times. Potassium was determined by the flame photometer while $\mathrm{Ca}$ and $\mathrm{Mg}$ were determined by Atomic Absorption Spectroscopy (Mukai, Horie, \& Goto, 1992).

\subsubsection{Leaf Nitrogen Content}

Leaf analysis has been used for a long time as a nutrient status diagnostic tool in perennial crops (Owuor \& Wanyoko, 1983). Fifty mature leaves per plot were sampled and taken to the laboratory for oven drying at $105{ }^{\circ} \mathrm{C}$ for 24 hours. The oven dried leaves were milled using the ${ }^{\mathbb{B}}$ Ramtons coffee miller and nitrogen determined using the Kjeldahl method (Okalebo et al., 2002).

\subsubsection{Yield Determination}

Tea was plucked at 7-10 days interval and the weight per plot recorded at every plucking round. The yield was converted to $\mathrm{kg}$ made tea per hectare per year $\left(\mathrm{kg} \mathrm{MT} \mathrm{ha} \mathrm{y}^{-1} \mathrm{y}^{-1}\right)$ using the following equation: $\left(n^{*} a^{*} 0.225\right) / \mathrm{b}$.

Where: $n$ is green leaf yield per plot, $a$ is plant population per hectare, 0.225 is the factor converting green leaf to made tea (Owuor \& Wanyoko, 1983) and $b$ is the number of plants per plot.

\subsubsection{Quality (Theaflavin, Thearubigins and Caffeine) Determination}

Two kilograms of tea (two leaves and a bud) were plucked, withered for $22 \mathrm{hrs,} \mathrm{macerated} \mathrm{using} \mathrm{a} \mathrm{miniature}$ 
CTC machine, fermented at $22^{\circ} \mathrm{C}$ for 90 minutes and then fired using miniature fluid bed drier (Tea craft, UK) at $120^{\circ} \mathrm{C}$ for 20 minutes before lowering to $100^{\circ} \mathrm{C}$ for 10 minutes to achieve a moisture content of about $3 \%$.

\subsubsection{Theaflavin Analysis}

The Flavognost method (Hilton, 1974) was used to determine total theaflavins content. Black tea (9 gm) was added to $375 \mathrm{ml}$ boiling water in a vacuum flask, shaken for 10 minutes, filtered and cooled to room temperature. The infusion $(10 \mathrm{ml})$ was pipetted into a $25 \mathrm{ml}$ volumetric flask where $10 \mathrm{ml}$ of Isobutyl methyl ketone (IBMK) was added, shaken for 15 minutes and transferred to a test tube to allow layers to separate. The upper layer ( $2 \mathrm{ml})$ was pipetted into a test tube where ethanol $(4 \mathrm{ml})$ and flavognost reagent $(2 \mathrm{ml})$ were added and shaken for two minutes before allowing colour development for 15 minutes. Absorbance was read on a Cecil Digital ${ }^{\mathbb{B}}$ spectrophotometer at $625 \mu \mathrm{m}$. Theaflavin was determined as:

$$
\text { Theaflavin }\left(\mu \mathrm{mol} \mathrm{g} \mathrm{g}^{-1}\right)=\mathrm{A}_{625 \mathrm{~nm}} \times 47.9 \times 100 / \mathrm{DM}
$$

Where,

A is absorbance at $625 \mathrm{~nm}$; 47.9 is a conversion factor attributed to dilution effect in theaflavins analysis; DM is the percent dry matter content.

\subsubsection{Thearubigins}

Total thearubigins content was determined by cooling the filtered tea infusion mixed with IBMK (Roberts \& Smith, 1963). The different layers of the mixture were separately taken and made up with methanol alone, distilled water and methanol, sodium hydrogen carbonate and methanol, distilled water, oxalic acid and methanol. The mean absorbance of the different layers were then determined (Obanda et al., 2001).

\subsubsection{Caffeine}

Tea (100 mg) was put into a $125 \mathrm{ml}$ conical flask, $70 \mathrm{ml}$ boiling water added (Ikegaya et al., 1985) and then one gramme of sodium bicarbonate was then added before filtering and cooling the mixture to room temperature. The volume was made up to $100 \mathrm{ml}$ and caffeine extracted using chloroform that was later removed by a rotatory evaporator. The residue was dissolved in $25 \mathrm{ml}$ of water and subjected to HPLC analysis using a JASCO UVIDEC-100-11 (Japan Spectroscopic Company Ltd., Tokyo). The caffeine content was determined at $272 \mathrm{~nm}$, peak heights being read against a standard curve.

\subsection{Statistical Analysis}

Data collected was subjected to analysis of variance (ANOVA) using SAS version 9.0 statistical software package and means separated by Student- Newman-Keuls (SNK).

\section{Results and Discussion}

\subsection{Nitrogen Content}

The $\mathrm{N}$ content in the mature leaf of tea varied significantly with fertilizer type (Table 2). Kamau et al. (2003) noted comparable N content in Kenya. Generally, NPKS 25.5.5.5 fertilizer had the highest N leaf content probably because of high amounts of mineralizable $\mathrm{N}$. The $\mathrm{N}$ content of the mature leaf increased with fertilizer rate especially during season one. In season two, N content was higher especially for NPKS at 150 and $225 \mathrm{~kg} \mathrm{~N}$ $\mathrm{ha}^{-1}$. The increase in $\mathrm{N}$ content in the mature leaf with increase in fertilizer rate has previously been reported (Kamau et al., 2003). The low $\mathrm{N}$ leaf content under cattle manure is probably because it must undergo mineralization before nutrients are available for uptake (Shisanya et al., 2009). Enrichment level (1:2 and 1:4) did not vary in their effect on $\mathrm{N}$ content in mature leaf as was previously reported. Earlier studies did not find any difference in $\mathrm{N}$ content in the mature leaf when 25:5:5:5s and 20:10:10 fertilizers were applied (Kamau et al., 2003).

Generally, tea is classified as deficient, when $\mathrm{N}$ leaf content is less than $3 \%$, mildly deficient when it is between 3 and $3.5 \%$ and adequately supplied when beyond 3.5\% (Owuor \& Wanyoko, 1983). In the current study, $\mathrm{N}$ rates less than $150 \mathrm{~kg} / \mathrm{ha}$ showed deficiency. This is consistent with the recommendation that at least more than $150 \mathrm{~kg}$ $\mathrm{N}$ ha ${ }^{-1}$ should be applied in this area. 
Table 2. Effect of enriched cattle manure ratio and rate on Nitrogen (\%) content of a mature tea leaf

\begin{tabular}{|c|c|c|c|c|c|c|c|c|}
\hline \multirow{3}{*}{ Fertilizer type } & \multicolumn{4}{|c|}{ Season one } & \multicolumn{4}{|c|}{ Season two } \\
\hline & \multicolumn{4}{|c|}{ Fertilizer rate $\left(\mathrm{kg} \mathrm{N} \mathrm{ha}^{-1}\right)$} & \multicolumn{4}{|c|}{ Fertilizer rate $\left(\mathrm{kg} \mathrm{N} \mathrm{ha}^{-1}\right)$} \\
\hline & 0 & 75 & 150 & 225 & 0 & 75 & 150 & 225 \\
\hline T1 (NPKS) & $2.52^{\mathrm{bA}^{*}}$ & $2.86^{\mathrm{bA}}$ & $3.24^{\mathrm{aA}}$ & $3.43^{\mathrm{aA}}$ & $3.02^{\mathrm{bA} * *}$ & $2.89^{\mathrm{bA}}$ & $3.44^{\mathrm{aA}}$ & $3.49^{\mathrm{aA}}$ \\
\hline T2 (Cattle manure) & $2.54^{\mathrm{bA}}$ & $2.35^{\mathrm{aB}}$ & $2.77^{\mathrm{bB}}$ & $3.07^{\mathrm{aA}}$ & $3.01^{\mathrm{abA}}$ & $2.63^{\mathrm{bB}}$ & $3.02^{\mathrm{aAB}}$ & $3.43^{\mathrm{aA}}$ \\
\hline T3 (OM: NPKS 1:2) & $2.51^{\mathrm{bA}}$ & $2.46^{\mathrm{bB}}$ & $2.97^{\mathrm{bB}}$ & $3.16^{\mathrm{aA}}$ & $3.03^{\mathrm{aA}}$ & $2.90^{\mathrm{aA}}$ & $3.03^{\mathrm{aA}}$ & $3.25^{\mathrm{aA}}$ \\
\hline T4 (OM: NPKS 1:4) & $2.53^{\mathrm{bA}}$ & $2.48^{\mathrm{bB}}$ & $2.89^{\mathrm{bB}}$ & $3.10^{\mathrm{aA}}$ & $3.02^{\mathrm{aA}}$ & $2.87^{\mathrm{aA}}$ & $2.94^{\mathrm{aB}}$ & $3.41^{\mathrm{aA}}$ \\
\hline
\end{tabular}

Note. "Means followed by the same upper case letter in a column are not significantly different from each other; *** Means followed by the same lower case letter within a row are not significantly different from each other.

\subsection{Yield of Tea}

The yield of tea varied significantly with fertilizer type (Table 3). Generally, NPKS 25.5.5.5s fertilizer had the highest yield followed by enriched cattle manure and lastly cattle manure. Changing the enrichment ratio of cattle manures from 1:2 to 1:4 affected crop yield. The difference in yield is probably a result of differences in available $\mathrm{N}$.

Increasing the $\mathrm{N}$ fertilizer rate resulted in increase in crop yield. The difference in yield was however mainly noted at higher $(150 \mathrm{~kg}$ and $225 \mathrm{~kg}$ ) N rates. Similar findings were reported in other experiments on different N rate in Kenya (Wanyoko, 1997; TRFK, 2002). The increase in yield with enriched manures is probably because of improved nutrient release. The NPKS 25.5.5.5 fertilizer led to the highest yield probably because the N content is more available. Similar finding have been reported using a mixture of NPK 2:2:0 and cattle manure (Shisanya et al., 2009). The low amounts of available $\mathrm{N}$ from organic manure may be responsible for the low yields (Phukan et al., 2008). Season one had higher yield compared to season two. The annual crop yield variation observed is a common characteristic of tea where factors such temperatures, rainfall, amount of rainfall and distribution vary (Dutta et al., 2010).

Table 3. Effect of rate and ratio of cattle manure enrichment on annual yield $\left(\mathrm{kg}\right.$ made tea ha $\left.{ }^{-1}\right)$ of tea

\begin{tabular}{|c|c|c|c|c|c|c|c|c|}
\hline \multirow[t]{2}{*}{ Fertilizer type } & \multicolumn{4}{|c|}{ Season One } & \multicolumn{4}{|c|}{$\begin{array}{l}\text { Season Two } \\
\text { Fertilizer rate }\left(\mathrm{kg} \mathrm{N} \mathrm{ha}^{-1}\right)\end{array}$} \\
\hline & 0 & 75 & 150 & 225 & 0 & 75 & 150 & 225 \\
\hline T1 (NPKS) & $1287^{\mathrm{aC} *}$ & $2769^{\mathrm{aB} * *}$ & $3767^{\mathrm{aA}}$ & $3925^{\mathrm{aA}}$ & $723^{\mathrm{aC}}$ & $1234^{\mathrm{bB}}$ & $2161^{\mathrm{abA}}$ & $2564^{\mathrm{aA}}$ \\
\hline T2 (Cattle manure) & $1304^{\mathrm{aB}}$ & $1933^{\mathrm{bAB}}$ & $2479^{\mathrm{bAB}}$ & $2903^{\mathrm{bA}}$ & $722^{\mathrm{aB}}$ & $1261^{\mathrm{bAB}}$ & $1713^{\mathrm{bAB}}$ & $1776^{\mathrm{aA}}$ \\
\hline T3 (OM: NPKS 1:2) & $1284^{\mathrm{aC}}$ & $2609^{\mathrm{aAB}}$ & $3475^{\mathrm{aA}}$ & $3719^{\mathrm{abA}}$ & $721^{\mathrm{aA}}$ & $1438^{\mathrm{aA}}$ & $1658^{\mathrm{bA}}$ & $2108^{\mathrm{aA}}$ \\
\hline T4 (OM: NPKS 1:4) & $1298^{\mathrm{aC}}$ & $2578^{\mathrm{aB}}$ & $4055^{\mathrm{aA}}$ & $4127^{\mathrm{aA}}$ & $720^{\mathrm{aB}}$ & $1388^{\mathrm{aAB}}$ & $2356^{\mathrm{aA}}$ & $2170^{\mathrm{aA}}$ \\
\hline
\end{tabular}

Note. ${ }^{*}$ Means followed by the same lower case letter in a column are not significantly different from each other;

${ }^{* *}$ Means followed by the same upper case letter within a row are not significantly different from each other.

\subsection{Tea Quality}

\subsubsection{Theaflavin (TF) and Thearubigins (TR)}

Theaflavin is the plain black tea quality parameter responsible for the astringency (briskness) and brightness of black tea (Wright et al., 2002; Owuor et al., 2006). Fertilizer type varied significantly in their effect on the TF content (Table 4). 
Table 4. Effects of fertilizer type and rate on Theaflvain $(\mu \mathrm{mol} / \mathrm{gm})$ content in made tea

\begin{tabular}{llllc}
\hline \multirow{2}{*}{ Fertilizer type } & \multicolumn{3}{c}{ Fertilizer rate $\left(\mathrm{kg} \mathrm{N} \mathrm{ha}^{-1}\right)$} \\
\cline { 2 - 5 } & 0 & 75 & 150 & 225 \\
\hline T1 (Cattle manure) & $23.29^{\mathrm{a}^{*} \mathrm{~A}^{* *}}$ & $20.75^{\mathrm{aB}}$ & $22.19^{\mathrm{aB}}$ & $19.11^{\mathrm{aC}}$ \\
T2 (OM: NPKS 1:2) & $23.48^{\mathrm{aA}}$ & $20.7^{\mathrm{aA}}$ & $18.78^{\mathrm{aA}}$ & $18.24^{\mathrm{aC}}$ \\
T3 (OM: NPKS 1:4) & $23.96^{\mathrm{aA}}$ & $21.8^{\mathrm{aB}}$ & $15.87^{\mathrm{bC}}$ & $17.86^{\mathrm{aC}}$ \\
T4 (NPKS) & $23.44^{\mathrm{aA}}$ & $19.53^{\mathrm{bB}}$ & $17.23^{\mathrm{bC}}$ & $15.59^{\mathrm{aC}}$ \\
\hline
\end{tabular}

Note. "Means followed by the same lower case letter in a column are not significantly different from each other; ${ }^{* *}$ Means followed by the same upper case letter within a row are not significantly different from each other.

Inorganic fertilizer NPKS 25.5.5.5 had the lowest TF content. Higher N rate had significantly lower the TF levels. Increase in $\mathrm{N}$ rate has been noted to increase the accumulation of free amino acid but reduce production of catechins (Ruan et al., 2010). Presence of free amino acids and catechin favour green and black tea quality respectively (Mukai et al., 1992). The decrease in TF content was more observed with NPKS 25:5:5:5s and enriched manures. Low black tea quality has been attributed to inhibition of key enzymes involved in the assimilation of amide amino acid and ammonia (Srivastava et al., 1982). The $\mathrm{N}$ in the inorganic fertilizer may have increased the accumulation of amino and fatty acids but reduced the catechins level leading to production of black tea with low TF levels. The decrease in TF levels with increase in NPK fertilizer rates has previously been noted (Owuor et al., 2011).

Thearubigin (TR) is an important plain black tea quality parameter that contributes to colour and thickness (mouth-feel). Fertilizer type and rate did not significantly affect the TR content (Table 5). Previous studies did not also find any effect of fertilizer type and rate on TR level (Owuor et al., 2011).

Table 5. Effects of fertilizer type and rate on Thearubigins (\%) content in made tea

\begin{tabular}{lllll}
\hline \multirow{2}{*}{ Fertilizer type } & \multicolumn{3}{c}{ Fertilizer rate $\left(\mathrm{kg} \mathrm{N} \mathrm{ha}^{-1}\right)$} \\
\cline { 2 - 5 } & 0 & 75 & 150 & 225 \\
\hline T1 (Cattle manure) & $2.96^{\mathrm{a}^{\mathrm{A} \mathrm{A}^{* *}}}$ & $3.03^{\mathrm{aA}}$ & $3.02^{\mathrm{aA}}$ & $3.0^{\mathrm{aA}}$ \\
T2 (OM: NPKS 1:2) & $2.95^{\mathrm{aA}}$ & $2.95^{\mathrm{aA}}$ & $3.11^{\mathrm{bB}}$ \\
T3 (OM: NPKS 1:4) & $2.94^{\mathrm{aA}}$ & $3.04^{\mathrm{bB}}$ & $3.0^{\mathrm{aB}}$ & $2.97^{\mathrm{aA}}$ \\
T4 (NPKS) & $2.99^{\mathrm{aA}}$ & $2.99^{\mathrm{aA}}$ & $2.80^{\mathrm{cA}}$ & $2.91^{\mathrm{aA}}$ \\
\hline
\end{tabular}

Note. "Means followed by the same lower case letter in a column are not significantly different from each other; ${ }^{* *}$ Means followed by the same upper case letter within a row are not significantly different from each other.

\subsubsection{Caffeine}

Caffeine is an important plain black tea quality parameter responsible for the stimulatory effects (Owuor et al., 2011). The caffeine content varied with fertilizer type (Table 6).

Table 6. Effects of fertilizer type and rate on caffeine content (\%)

\begin{tabular}{lllll}
\hline \multirow{2}{*}{ Fertilizer type } & \multicolumn{3}{c}{ Fertilizer rate $\left(\mathrm{kg} \mathrm{N} \mathrm{ha}^{-1}\right)$} \\
\cline { 2 - 5 } & 0 & 75 & 150 & 225 \\
\hline T1 (Cattle manure) & $1.33^{\mathrm{a}^{*} \mathrm{~A}^{* *}}$ & $1.44^{\mathrm{aA}}$ & $1.42^{\mathrm{aA}}$ & $1.44^{\mathrm{aA}}$ \\
T2 (OM: NPKS 1:2) & $1.33^{\mathrm{aA}}$ & $1.49^{\mathrm{aB}}$ & $1.53^{\mathrm{bB}}$ & \\
T3 (OM: NPKS 1:4) & $1.34^{\mathrm{aA}}$ & $1.51^{\mathrm{aB}}$ & $1.56^{\mathrm{bB}}$ & $1.7^{\mathrm{bB}}$ \\
T4 (NPKS) & $1.38^{\mathrm{aA}}$ & $1.53^{\mathrm{aB}}$ & $1.73^{\mathrm{bB}}$ & $1.81^{\mathrm{cB}}$ \\
\hline
\end{tabular}

Note. "Means followed by the same lower case letter in a column are not significantly different from each other;

${ }^{* *}$ Means followed by the same upper case letter within a row are not significantly different from each other. 
Cattle manure had the lowest caffeine content probably because of the lower amount of mineralizable N. Increasing the $\mathrm{N}$ rates of cattle manure had no effect on caffeine content. Higher caffeine content in plants supplied with ammonium compared to the nitrate $\mathrm{N}$ has been noted (Li et al., 2013). Apart from cattle manure, increase in $\mathrm{N}$ levels beyond zero resulted in higher levels of caffeine probably because there is a critical $\mathrm{N}$ level that influences the caffeine content. A linear increase in caffeine content with increase in NPK 25.5.5.5 fertilizer rates up to $450 \mathrm{~kg} \mathrm{~N} \mathrm{ha}^{-1}$ has previously been noted. The increase in caffeine content with increase in $\mathrm{N}$ rate has been attributed to increased $\mathrm{N}$ metabolism which favours the synthesis of amino acid and caffeine (Srivastava et al., 1982).

\section{Conclusions}

Fertilizer type and rate significantly affect the yield and quality of tea. The effect of fertilizer type varied with the level of mineralizable N. Cattle manure resulted in lower tea yield and $\mathrm{N}$ levels, in the mature leaf. Enrichment of cattle manure resulted, higher tea yield and $\mathrm{N}$ in the mature leaf. The current results suggest that enriched manures can also be used instead of NPKS. The increase in fertilizer rate results in increased crop yield and N content. This implies that enriched manures can be used for sustainable tea production.

\section{References}

Dutta, R., Stein, A., Smaling, E. M. A., Bhagat, R. M., \& Hazarika, M (2010). Effects of plant age, and environmental conditions and management factors on tea yield in Northeast India. Agronomy Journal, 102, 1290-1301. http://dx.doi.org/10.2134/agronj2010.0091

Hilton, P. J. (1974). Encyclopedia of Industrial Chemical Analysis (p. 455). In F. O. Snell \& L. S. Ettre (Eds.). New York: John Wiley \& Sons.

Ikegaya, K. (1985). Nippon Shokuhin Kogyo. Gakkaishi, 32, 6.

Kamau, D. M., Owuor, P. O., \& Wanyoko, J. K. (2003). Long term effects of rates and types of nitrogenous fertilizers on high yielding clone AHP S15/10 tea (I): Yields and nutrients uptake. Tea, 24, 14-20.

Kamau, D. M., Wanyoko, J. K., Nyabundi, K. W., \& Sitienei, K. (2011). Effects of organic manures on tea yields and soil properties in Kenya. A paper presented during the Tea Organic-Low Carbon International Symposium, Guangyuan, China.

Kebeney, S. J., Kamau, D. M., Othieno, C.O., Ng'etich, W. K., \& Owuor, P. O. (2010). Changes in soil chemical properties and leaf nutrients content in tea due to nitrogen fertilizer rates and application intervals. Tea, 31, $22-27$.

Li, S., Wang, Z., \& Steward, B. A. (2013). Responses of Crop Plants to Ammonium and Nitrate N. Advances in Agronomy, 118, 210-397. http://dx.doi.org/10.1016/B978-0-12-405942-9.00005-0

Mukai, T., Horie, H., \& Goto, T. (1992). Differences in free amino acids and total nitrogen contents among various prices of green teas. Tea Research J., 76, 45-50. http://dx.doi.org/10.5979/cha.1992.76_45

Obanda, M., Owuor, P. O., \& Mangale, R. (2001). Changes in chemical and sensory quality of black tea due to variation of fermentation time and temperature. Food chemistry, 75, 395-404. http://dx.doi.org/10.1016/S0308-8146(01)00223-0

Okalebo, J. K., Gathua, K. W., \& Woomer, P. L. (2002). Laboratory methods of soil and plant analysis (A working manual, 2nd ed.). TSBF-CIAT and SACRED Africa, Nairobi. Kenya.

Omare, M. N., \& Woomer, P. L. (2003). The Organic Agriculture Movement in Kenya. In E. N. Savala, M. N. Omare \& P. L. Woomer (Eds.), Organic Resource management in Kenya: Perspectives and guidelines (pp. 163-172). Forum for Resource Management and Agricultural Technologies, Nairobi, Kenya.

Owino-Gerroh, C. (1991). Acidity in tea and the related constraints-A review. Tea, 12, 52-55.

Owuor, P. O., \& Wanyoko, J. K. (1983). Fertilizer use advisory service: A reminder to famers. Tea, 4, 3-7.

Owuor, P. O., Kamau, D. M., Kamunya, S. M., Msomba, S. W., Uwimana, M. A., Okal, A. W., \& Kwach, B. O. (2011). Effects of genotypes, environment and management on yield and quality of black tea. In E. Lichtfouse (Eds.), Genetics, biofuels and Local farming systems, Sustainable Agricultural reviews (pp. 277-307). Springer Science \& Business. http://dx.doi.org/10.1007/978-94-007-1521-9_10

Owuor, P. O., Ng'etich, W. K., \& Obanda, M. (2002). Quality response of clonal black tea to nitrogen fertilizer, plucking interval and plucking standard. Journal of the Science of Food and Agriculture, 80, 439-446. http://dx.doi.org/10.1002/(SICI)1097-0010(200003)80:4\%3C439::AID-JSFA546\%3E3.3.CO;2-U 
Owuor, P. O., Obanda, M., Apostolides, Z., Wright, L. P., Nyirenda, H. E., \& Mphangwe, N. I. K. (2006). The relationship between the chemical plain black tea quality parameters and black tea colour, brightness and sensory evaluation. Food Chemistry, 97, 644-653. http://dx.doi.org/10.1016/j.foodchem.2005.04.027

Phukan, I., Baruah, A., \& Bhagat, R. M. (2008). Influence of combined use of organic, inorganic and bio fertilizer sources on chemical, physical and biological properties of tea soil. Two and a Bud, 55, 28-35.

Roberts, E. A. H., \& Smith, R. F. (1963). Phenolic substances of manufactured tea. II, Spectroscopic evaluation of tea liquors. J. of Science and Food Agriculture, 14, 889-900. http://dx.doi.org/10.1002/jsfa.2740141003

Ruan, J., Haerdter, R., \& Gerendas, J. (2010). Impact of N supply on the C/N allocation: A case study on amino acids and cateching in green tea plant. Plant Biol, 12, 724-734. http://dx.doi.org/10.1111/j.1438-8677.2009.00288.x

Shisanya, C. D., Mucheru, M. W., Mugendi, D. N., \& Kung'u, J. B. (2009). Effect of organic and inorganic nutrient sources on soil mineral nitrogen and maize yields in central highlands of Kenya. Soil Tillage Research, 103, 239-246. http://dx.doi.org/10.1016/j.still.2008.05.016

Srivastava, R. A. K., Mathur, S. N., \&Dev Chaudhury, M. N. (1982). Physiological aspects of different levels of nitrogen utilization in Camellia sinensis with respect to yield and quality of made teas. Indian $J$ of Experimental Biology, 20, 152-155.

TRFK. (2002). Tea Growers Handbook (5th ed.). Kenya, Kericho: The Tea Research Foundation of Kenya.

Vanlauwe, B., Wendt, J., \& Diels, J. (2001). Combined application of organic matter and fertilizer. In G. Tian, F. Ishida \& J. D. H. Keating (Eds.), Sustaining Soil Fertility in West Africa (SSA Special Publication No. 58). Soil Science Society of America, Madison, USA.

Wanyoko, J. K. (1997). Advances in fertilizer use in Kenyan tea industry. Tea, 18, 123-131.

Wright, L. P., Maphangwe, N. I. K., Nyirenda, H. E., \& Apostolides, Z. (2002). Analysis of the theaflavin composition in the black tea (Camellia sinensis) for predicting the quality of tea produced in Central and Southern Africa. J. of Science Agriculture, 82, 517-525.

\section{Copyrights}

Copyright for this article is retained by the author(s), with first publication rights granted to the journal.

This is an open-access article distributed under the terms and conditions of the Creative Commons Attribution license (http://creativecommons.org/licenses/by/3.0/). 